\title{
ABORIGINAL SELF-GOVERNMENT' AND THE CONSTRUCTION OF CANADIAN CONSTITUTIONAL IDENTITY
}

\author{
MICHAEL ASCH*
}

In this article, the author examines the need for constitutional recognition and protection of the political collective rights of minority groups in Canada, particularly those of Aboriginal nations. The author asserts that Canada's present constitutional approach to minority collective rights is one of "indirect consociation." an approach which embraces the ideology of "universalism" and does not expressly recognize or protect minority ethmonational communities. This is ineffective as it generates political instability. He examines both Canadian constitutional thinking as well as the thoughts of Aboriginal nations on the right to self-government and discusses the conflicting theories behind each position. Finally, the author suggests that the solution to resolving this conflict between minority and majority political rights is for Canada to adopt a "direct consociation" approach. This approach would recognize expressly and protect the political rights of Aboriginal nations and other minorities, based on the concept of equality, as opposed to continuing colonialist or assimilationist approaches which only serve to heighten inequality and political tension.
Dans le présent article. l'auteur examine la nécessité de la reconnaissance constiturionnelle et de la protection des droits politiques collectifs des groupes minoritaires canadiens, surtout ceux des peuples autochtones. L'auteur déclare que le Canada adopte actuellement une approche constitutionnelle de aconsociation indirectes, qui épouse lidéologie de l"auniversalismes et ne reconnaît pas expressément ni ne protège les collectivités ethmonationales minoritaires. Cette approche inefficace est source d' instabilité politique. Il examine à la fois la pensée constitutionnelle canadienne et les réflexions des nations autochtones sur le droit à l'autonomie gowvernementale, ef discute des théories divergentes qui animent ces deux prises de position. Finalemem, I auteur suggère que I"approche de rconsociation directe" permettrait au Canada de résoudre ce conflit entre les droits politiques de la majorité et des minorités. Cette approche reconnaîtrait et protégerait explicitement les droits des peuples autochtones et des autres minorités en se fondant sur le principe d'égalité. contrairement aux approches colonialistes et assimiliationnistes qui sont toujours en vigueur, qui contribuent seulement à augmenter les inégalités et les tensions politiques.

\section{TABLE OF CONTENTS}

I. INTRODUCTION .....................4 466

II. CANADIAN STATE IDEOLOGY AND ABORIGINAL POLITICAL RIGHTS . . . . . . . . . . . . . 470

A. THE CONSTITUTION ACT, $1867 \ldots \ldots \ldots \ldots \ldots \ldots . \ldots 42$

- Department of Anthropology, University of Alberta, Edmonton, Alberta. The author wishes to thank Peter Meekison, Richard Price. Brian Slattery and Sharon Venne for their helpful and insightful comments, as well as to acknowledge the support of the Anthropology Committee of SSHRCC which provided research funds used in the preparation of this paper. This paper was originally presented at the conference on Ethnonationalism held at the University of Toronto, December, 1990.

I. I understand that the term Indigenous is now replacing Aboriginal as the term of self-designation among Indigenous nations in Canada. I also understand that the term government or governance is replacing self-government. Thus, perhaps a year from now, it might have been conventional to entitle this paper "Indigenous Government and the Construction of Canadian Constitutional Identity." I decided to use "Aboriginal Self-Government" because, at this moment, the convention is not in place and this phrase is better used to convey the general topic I intend to address. 
B. THE CONSTITUTION ACT, $1982 \ldots \ldots \ldots \ldots \ldots \ldots . \ldots 44$

C. RECENT SUPREME COURT DECISIONS

AND CONSTITUTIONAL INTERPRETATION . . . . . . . . 476

III. CANADIAN STATE POLICY AND ABORIGINAL

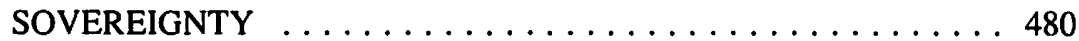

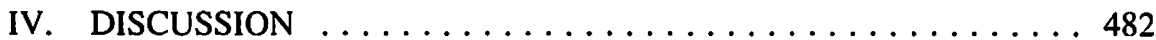

V. CONCLUSIONS .................... 487

\section{INTRODUCTION}

We are at a pivotal moment in Canadian constitutional history. Notwithstanding admonitions that the economy or free trade or another issue is the number one priority in the minds of the voters, now is the time when we must begin to act on resolving the crisis of community that besets us.

The crisis of community is itself a crisis in our constitutional approach to resolving one major dilemma of the modern nation-state: the relationship between the collective political rights of collectivities that find themselves to be minorities ${ }^{2}$ within an existing state with political rights based on the principle of majority rule. At the same moment, we are confronted by the need to consider the accommodation of two distinct kinds of such communities within Canada; the regional and the ethnonational. ${ }^{3}$ Regional and ethnonational voices that appeal for an immediate reappraisal of our institutions include those from Quebec, the West, the North and Aboriginal peoples. For each, at least in principle, one alternative to the status quo is separation and thus independence from the majority.

For both regional and ethnonational communities in Canada, there are alternatives to the choice between the constitutional status quo and separation. My research has focused primarily on those related to ethnonational that find themselves to be minorities within Canada. This research has led me to explore the concept of "consociation" as it has been described in anthropological theory. ${ }^{4}$

2. My use of the phrase "collectivities that find themselves to be minorities" rather than to define these groups as "minorities" is to help clarify that I do not accept that proposition that there is a "special class" of nations or peoples defined as "minorities" which has a different and presumably somewhat diminished right to self-determination than do groups not defined as "minorities." In fact, a "minority," as I am viewing the term, possesses rights that are no different than those of a majority. The only difference is that, at the present time, there is no recognition of these rights. Thus, for example, Ukraine, which may have been considered a "minority" population at one point, has become a "majority" population with no actual change in their internal self-definition. I am using the term "minority" in this paper to mean only "collectivities that find themselves to be minorities within an existing state" and in no other sense.

3. W. Connor, "The Politics of Ethnonationalism" (1973) 27 Joumal of International Affairs 1.

4. M.G. Smith, "Some Developments in the Analytic Framework of Pluralism" in Leo Kuper and M.G. Smith, eds., Pluralism in Africa (Berkeley: University of California, 1969) 415. 
This term was developed almost simultaneously in anthropology and political science to mean two slightly different things. ${ }^{6}$ In the anthropological view, consociation represents one of the fundamental ways in which state ideology identifies citizens with respect to ethnonational identity. In states that follow "universalistic" ideology (such as the United States of America) state ideology identifies citizens solely as individuals and recognizes no ethnonational communities. In contrast, states that follow "consociational" ideology identify citizens both as individuals and as members of various ethnonational communities and act to ensure equality of protection for both individual and minority ethnonational collective rights. ${ }^{7}$ In the modern world, liberal-democratic states are commonly based on universalistic premises and only rarely on consociational ones.

In order to better understand the nature of consociational states and how they act to protect collective political rights, I have found it useful to divide them into two distinct types. ${ }^{8}$ While each results in the protection of the collective political rights of specified ethnonational minorities, each does it by use of different constitutional principles. As a result, state ideology with respect to the rights of ethnonational minorities acquires very different characteristics.

The first type I define as "direct" consociation. Here state ideology expressly acknowledges the existence of various ethnonational collectivities (as for example in its constitutional charter) and thus protection is afforded explicitly to specified and named ethnonational communities.

The second type I define as "indirect" consociation. In this case, state ideology does not explicitly recognize or protect minority ethnonational communities. Rather, its ideology espouses the philosophy of "universalism." Protection of specific ethnonational minorities is created as a consequence of other principles. One method of achieving this goal is to divide powers between federal and provincial levels of government and then to ensure that the specified minority ethnonational collectivity forms a majority within a particular provincial jurisdiction. In contrast to a direct consociation, in this form the constitutional charter would not refer explicitly to any ethnonational collectivity. Thus, the ethnonational minority's control can be maintained only so long as no constitutional amendments are passed that directly attack its legislative jurisdiction and, in real political terms, only so long as it retains a majority status within a recognized political jurisdiction.

5. A. Lijphart, Democracy in Plural Societies: A Comparative Exploration (New Haven: Yale University, 1977).

6. M. Asch, Home and Native Land: Aboriginal Rights and the Canadian Constitution (Toronto: Methuen Canada, 1984 and Nelson Canada, 1988).

7. For example, see V. Van Dyke, "The Cultural Rights of Peoples" (1980) 2(2) Universal Human Rights Journal I, regarding Belgium. I do not mention ethnonational rights of the majority because their rights are, generally, protected through the fact that this community is the majority. Indeed, it is my experience that majority communities tend to be so secure in their view of their rights that they do not see themselves as belonging to a community.

8. Supra, note 5 and M. Asch, "Consociation and the Resolution of Aboriginal Political Rights: The Example of the Northwest Territories, Canada II" (1990) X(2) Culture 93. 
In my view, Canada, as the division of powers has been organized through the Constitution Act, 1867, represents an attempt to construct an indirect consociation with respect to the French-fact as it exists in Quebec. ${ }^{9}$ Thus, Canada espouses an ideology of "universalism" in that there are no "named" and "recognized" ethnonational collectivities in the constitution. ${ }^{10}$ However, because the majority of the population of Quebec belongs to a distinct ethnonational community the division of powers between provincial and federal levels as well as the sanctity of the borders of Quebec provides a de facto consociational result.

This result represents a judicious compromise. From the francophone point of view, Canada can be ideologically constructed to be a direct consociation between the French and the "English." On the other hand, an anglophone point of view, Canada can be ideologically constructed to be a "universalistic" state that happens to be organized under principles of "federalism."

While this "compromise" may have produced stability for over a century, it is now generating instability. This can be exemplified in the Meech Lake debate. If Canadian constitutional identity were already based on principles of direct consociation, then neither the naming of Quebec as a distinct society within Canada nor the need to protect minority collective rights (such as through the language sign law) would have been so controversial in anglophone Canada. However, as state ideology, at least as it is constructed by anglophone Canada, adheres to the philosophy of universalism, the naming or acceptance of Quebec as a distinct society as well as the recognition of a need to protect collective minority rights over individual rights was eschewed. I would argue that this situation was created in large measure because of the ambiguities in constitutional ideology inherent in the use of principles of "indirect" consociation.

It is my view that the use of principles of direct consociation represent a better solution to the problem of minority-majority ethnonational relations than does the principle of "universalism." Elsewhere, I discuss methods whereby the direct consociational

9. Section 93 of the Constitution Act, 1867 does expressly recognize the collective education rights of particular religious communities. Given the cultural context within which the 1867 Constitution was written, this can be taken as a code for protecting certain ethnonational rights. In this sense, there is the "shadow" of direct consociational accommodation even within that document.

There are a number of other interpretations of Canadian state ideology. Of these, one very significant alternative is "The Compact Theory." In this view, Canada is a direct consociation between two founding peoples: The "English" and the "French." This thesis, not surprisingly, has found much of its support in Quebec. The status of this thesis within official Canadian state ideology was tested during the patriation debate and in particular by the actions of the Trudeau government in patriating the constitution without the overt approval of Quebec ( $R$. Van Loon and M. Whittington, The Canadian Political System: Environment, Structure and Process, 4th ed. (Toronto: McGraw-Hill Ryerson, 1987). The subsequent Supreme Court of Canada decision, which made it clear that, while Quebec's approval was a "convention," it was not a legal requirement, adds considerable weight to the view that, at least in its official ideology, Canada espouses the universalistic thesis that is the hallmark of indirect consociation and is so prevalent in the thinking of anglophone Canada. 
approach" may be used as a means to reconcile Aboriginal collective political rights with a public government majority-rule system in the western Northwest Territories.

Here I intend to focus on a related matter: the need to reconstitute our constitutional identity with regard to the political status of Aboriginal nations ${ }^{12}$ that find themselves within Canada. In particular, I will address the assertion that Aboriginal nations have an "inherent" right to self-determination and self-government and that this inherent right must find both practical and constitutional recognition by the Canadian state.

The nub of my concern is this. In my view, current constitutional ideology greatly devalues this proposition. It does so largely because, on an intellectual level, we have not accepted the principles of direct consociation and have not found a need, a will or a means to work at resolving the matter of Aboriginal self-government through principles of indirect consociation. Indeed, in our constitutional ideology, Aboriginal peoples, as opposed to the French-fact, represent one component among many "ethnocultural" communities none of which, given the universalistic ideology that dominates thinking in "non-French" Canada should have any special collective political rights.

But I go further. I argue that our espoused "universalistic" ideology in fact masks assumptions about the moral legitimacy of our occupation of Canada that have colonial and racist overtones. In other words, state ideology with respect to the Aboriginal question not only runs counter to the reasonable resolution of legitimate political rights for Aboriginal nations but can be seen to give support to principles that are morally repugnant. Thus, I would argue that if Canada (or Quebec should it decide to separate) is ever to build a nation that can accommodate the aspirations of Aboriginal nations, the ideology of universalism must be overturned.

The body of this paper is divided into two major sections. In the first, I discuss in some detail the constitutional ideology that orients Canadian constitutional thinking on Aboriginal self-government. I focus here primarily on a textual examination of the Constitution Acts of $1867^{13}$ and $1982 ; ;^{14}$ government policy in areas such as comprehensive land claims, and recent Supreme Court of Canada decisions such as the Sparrow case. ${ }^{15}$ In this context, I also address the views of the Aboriginal nations with respect to their right to self-government and its recognition in the Constitution. The second section deals more specifically with the ideological basis for the assertions of government. I close with a brief discussion of the implications of rejecting or accepting

\footnotetext{
II. Asch (1990), supra, note 8.

12. I am using Aboriginal nations rather than First Nations because, as I understand it, the Metis Nation may not accept the term with respect to themselves. I might also describe these nations as Indigenous nations.

13. Constitution Act, 1867 (U.K.) 30 \& 31 Vict., c. 3.

14. Constitution Act, 1982, being Schedule B of the Canada Act. 1982 (U.K.) 1982, c. 11 [hereinafter Constitution Act, 1982].

15. R. v. Sparrow (1990), 70 D.L.R. (4th) 385 (S.C.C.).
} 
either party's position on the question of Aboriginal political rights. Specifically, I will indicate that the approach to Aboriginal self-government based on principles of "direct consociation" given the form in which Aboriginal nations suggest it will be expressed, will help us to generate the very kind of process needed in order to promote reconciliation between peoples and regions in this country.

\section{CANADIAN STATE IDEOLOGY AND ABORIGINAL POLITICAL RIGHTS}

I have suggested above that Canadian state ideology masks assumptions about our occupation of Canada that have racist and colonial overtones. This is a serious charge, so let me hasten to add that I do not mean that Canadians are inherently racist or colonialist in their attitudes nor that they would support a state ideology that would overtly espouse such principles. Rather, I believe that these attitudes flow mainly from our neglect of examining older historical assumptions about Aboriginal nations and from some of the premises of universalism itself. In fact, I believe that Canadians in general, regardless where we reside or to which ethnonational collectivity we belong would find it morally repugnant to support a state that expressed such principles. This is one reason why I think the mere articulation of the racist and colonial implications of certain facets of current constitutional ideology will have a salutary effect on making necessary changes.

Let me begin by illustrating what I mean. I thought Canada had come a long way since British Columbia Chief Justice Davey felt comfortable in stating with regard to the Aboriginal rights of the Nishga in 1970:

(The Nishga) ...were at the time of settlement a very primitive people with few of the institutions of civilized society.... (Therefore), I have no evidence to justify a conclusion that the aboriginal rights claimed by the successors of these primitive peoples are of a kind that it should be assumed the Crown recognized them when it acquired the mainland of British Columbia by occupation. ${ }^{16}$

In fact, I would mark the admonition by Canadian Supreme Court Justice Hall to Justice Davey's remarks as crucial to the development of our constitutional thinking about the place of Aboriginal nations within Canada. He said:

The assessment and interpretation of historical documents and enactments tendered in evidence must be approached in light of present-day research and knowledge, disregarding ancient concepts formulated when understanding of the customs and cultures of our original people was rudimentary and incomplete and when they were thought to be wholly without cohesion, laws, or culture, in effect a subhuman species.... ${ }^{17}$ 
It is this approach which, I believe, is necessary to our rethinking of the pejorative assumptions and implications of our current state ideology with respect to accepting the premise of an inherent right to self-determination and self-government.

Yet, the problem remains and not just "intellectually." It has a practical effect on the world. The following is excerpted from the "Statement of the Attorney General of Canada's Position on Extinguishment, Diminution or Abandonment of Aboriginal Rights in the Claim Area." It was filed in December of 1989 by the Government in defense of a claim by the Gitksan-Wet'suwet'en Nation (referred to below as Gitksan). It says that regarding:

1. The plaintiffs' claim to ownership and jurisdiction over all the lands in the claim area.

The Attorney General of Canada responds:

Ownership and jurisdiction constitute a claim to sovereignty. If the Plaintiffs ever had sovereignty, it was extinguished completely by the assertion of sovereignty by Great Britain. ${ }^{13}$

What the second sentence actually suggests is that: 1) Canada doubts that the Gitksan were ever civilized enough to have sovereignty; but that 2 ) if they did have it, the mere assertion of sovereignty by Great Britain was enough to extinguish it. ${ }^{19}$ The acceptance of these assertions is found in the trial judge's reasons for judgment in this case. ${ }^{20}$

Such a line of argument is, in my view, racist and colonialist in spirit and intent. It flies not only in the face of the culturally relativist assumptions underlying Justice Hall's remarks cited above, but also and perhaps more importantly the spirit of relevant United

18. "Statement of the Attorney General of Canada's Position on Extinguishment, Diminuation or Abandonment of Aboriginal Rights in the Claim Area" (Attorney General of Canada, December, 1989).

19. I understand that this remark can be interpreted as merely stating a hypothetical possibility and is a fairly standard way in which lawyers will advance claims counter to those asserted by the other side. I feel, however, that this statement must be taken within the richer context I have provided. It has both moral and political implications. The analogy would be to say it is appropriate to argue counter to another person's claim that he or she is a human being that one doubts that the statement is true. It is morally inappropriate, notwithstanding that it is possible to utter. Equally, the statement has very significant political implications. This is not a private matter. It is the Attomey-General of Canada, speaking presumably for the people of Canada, who is asserting that certain people whom it defines as "fellow citizens" are less equal than others.

20. Delgamuukw v. B.C. (1989), 38 B.C.L.R. (2d) 176. For a more detailed discussion please see M. Asch, "Errors in the Delgamuukw Judgement: An Anthropological Perspective," a commentary prepared for the conference Delgamulkw and the Aboriginal Land Question," University of Victoria (10-11 September, 1991) unpublished ms., 24 pp. 
Nations declarations on the rights of colonized peoples, declarations to which Canada itself is a party. ${ }^{21}$

My point is that any constitutional ideology that enables the Attorney General of Canada to make such bald remarks and, as well to have these remarks supported by the courts, is unacceptable and must be changed. I am arguing that making such assumptions in 1989 would not have been possible were it not for some inherent bias in the current way in which we conceptualize the incorporation of Aboriginal nations into the Canadian state and society.

My question, then, is what is there in current constitutional thinking about the place of Aboriginal nations within Canada that gives support to such a statement? My provisional answer, which is based on my reading of primary texts such as the Constitution Acts of 1867 and $1982^{22}$ and is admittedly impressionistic follows below.

But first, one point. There is, of course, a strong and growing literature that lays out the history of Canadian political and legal thought as well as state policy on the topic. ${ }^{23}$ This history is important for an overall discussion of the evolution of constitutional thought on the topic. However, this is beyond the scope of this contribution. Here, I will focus on current thinking. I will do this primarily by examining a few basic sources, including some that are historical. I begin with the Constitution Act, 1867 or, as it was known, The British North America Act, 1867.

\section{A. THE CONSTITUTION ACT, 1867}

I begin with the Constitution Act, 1867 because it is our most fundamental constitutional document with respect to both the assertion of political "dominion" over the land mass now called Canada and the distribution of sovereign power that is its domain.

This document, as is common knowledge, ${ }^{24}$ indicates that the Canadian state is to be federal in nature with two levels of government; the federal and the provincial. It

21. See for example the "Declarations on the Granting of Independence to Colonial Countries and Peoples" (U.N. General Assembly Resolution 14 December 1960) which was adopted without a dissenting vote. For the test see Asch, supra, note 6.

22. I understand that I am using a common but not completely accurate form of representing the Constitution. Properly speaking, it is the Constitution Act, 1867 as amended in 1982 . However, while formally correct, this language does not convey the significant symbolic difference between the 1982 amendments and those that took place, from time to time, in the period prior to 1982. Because I wish to convey the symbolic development that the 1982 Act confers in the text, I use the "common" approach rather than the one that is formally correct.

23. See for example, P. Macklem, "First Nations Self-Government and the Borders of the Canadian Legal Imagination" (1991) 36 McGill L.J. 382 and B. Slattery, "Understanding Aboriginal Rights" (1987) 66 Can. Bar Rev. 727 and B. Slattery, "Aboriginal Sovereignty and Imperial Claims" (1991) 29 Osgoode Hall L.J. 1.

24. See for example, R. Van Loon and M. Whittington, The Canadian Political System: Environment, Structure, and Process, 4th ed. (Toronto: McGraw-Hill Ryerson, 1987). 
specifies clearly, primarily in ss. 91,92 and 93, the division of legislative responsibilities between the two levels of government.

Section 91 describes, specifically, the areas of legislative authority held by the Federal Government. These include, among other things, the right to pass laws about the regulation of trade and commerce (s. 91(2)), about taxation (s. 91(3)), about currency (s. 91(14)), and about the criminal law (s. 91(27)).

Sections 92 and 93 describe the power held by the provinces to pass laws. These, among other matters, include in s. 92: "the Management and Sale of the Public Lands belonging to the Province and of the Timber and Wood thereon" (s. 92 (5)), the establishment and maintenance of hospitals (s. 92(7)), property and civil rights in the province (s. 92(13)) and "Generally all Matters of a merely local or private Nature in the Province" (s. 92(16)). Section 93 deals with education and makes it a provincial responsibility (subject to certain limitations).

The preamble to the Constitution Act, 1867 makes it clear that the constitution was undertaken as an act of federal union by specific provinces in British North America. Thus, it assumes that the previous provincial authorities were autonomous entities (under the Queen). It suggests that one primary goal of the Act is to construct a "Constitution similar in Principle to that of the United Kingdom."25 However, the Constitution Act, 1867 is a-historical in that it makes no mention of earlier conditions out of which the union is to emerge and is not "ontological," for it asserts no founding philosophical principles, unlike the Constitution Act, 1982 which includes the Charter of Rights and Freedoms that begins with the words "Whereas Canada is founded upon principles that recognize the supremacy of God and the rule of law."26

Aboriginal people are mentioned in only one place in the original British North America Act, 1867. Section 91, which enumerates the powers of the Federal Government, specifically says: "the exclusive Legislative Authority of the Parliament of Canada extends to all Matters coming within the Classes of Subjects next hereinafter enumerated...."27 One of these matters, found in subsection 24 is "Indians and Lands reserved for the Indians. ${ }^{28}$ In other words, the BNA Act specifies that Indians and lands reserved for them fall under the exclusive legislative authority of the Federal parliament.

This subsection could be interpreted as meaning that it is only the Federal government which has the authority to negotiate with Indians and to regulate Indian affairs after negotiations have resulted in treaties of mutual consent. Indeed, such an interpretation seems very plausible when one examines the Constitution Act, 1867 in light of the

25. Ibid. at 637 .

26. Canadian Charter of Rights and Freedoms, Part I of the Constitution Act, 1982 (U.K.) 1982 c.11.

27. Supra, note 24 at 864.

28. Ibid. at 666 . 
undertakings such as are found in the Royal Proclamation of $1763^{29}$ and in the provision to deal with Native land claims contained in the Ruperts Land Order of $1870 .^{30}$ Indeed, I would hope and expect that such an interpretation will ultimately prove definitive in our constitutional thought.

The fact is that this interpretation is not now definitive. An alternative interpretation would be that s. 91 (24) in fact asserts unilateral dominion over Indians and lands reserved for Indians, subject only to dealing fairly with their claims.

Such a reading would rely, among other things, on the fact that the preamble to the Constitution Act, 1867 draws no attention to history but merely assumes that the parties, acting under the authority of the British Crown, have the unfettered right to form a federation and from the very specific way in which that Act divides all legislative authority within the dominion into either the federal or the provincial sphere. In other words, it relies on a decontextualized reading of the Act and assumes that, whereas silence must be interpreted narrowly, the written word must be interpreted broadly. I believe that it is the use of such an interpretive frame that lies behind the remarks of the Attorney General of Canada cited above.

\section{B. THE CONSTITUTION ACT, 1982}

The Constitution Act, 1982 deals with a number of fundamental constitutional matters that include most importantly the rights of individual citizens, minority language education rights and a method to amend the constitution itself. As I suggested above, it begins with a philosophical statement as a Preamble which, to repeat, says: "Whereas Canada is founded upon principles that recognize the supremacy of God and the rule of law." ${ }^{31}$ However, again, like the Constitution Act, 1867, it provides no historical context or justification for the assumption that Canada exists.

Three sections of the Constitution Act, 1982 make explicit reference to Aboriginal peoples. The first is $\mathbf{s}$. 25 . It states that:

\footnotetext{
The guarantee in this Charter of certain rights and freedoms shall not be construed so as to abrogate or derogate from any aboriginal, treaty or other rights or freedoms that pertain to the aboriginal peoples of Canada. ${ }^{32}$
}

In other words, it protects the rights of Aboriginal peoples from any legal interpretation that would diminish their force when they are in possible conflict with the application of the Charter of Rights and Freedoms.

\footnotetext{
29. Royal Proclamation of 1763, R.S.C. 1985, App. II, No. 1.

30. Rupert's Land Order, R.S.C. 1985 App. II, No. 7.

31. Supra, note 24 at 697.

32. Supra, note 14.
} 
The second is s. 35. It defines the "aboriginal peoples of Canada" as including Indians, Inuit and Metis; a clause that is of particular importance to the Metis who previously were in a potentially ambiguous legal position regarding their status as Aboriginal peoples. It also assures among other matters that the rights obtained through the settlement of modern land claims would be considered constitutionally equivalent to treaty rights and hence would find constitutional protection under the Constitution Act, 1982. Finally, and most crucially, s. 35 states that: "The existing Aboriginal and treaty rights of the Aboriginal peoples of Canada are hereby recognized and affirmed." ${ }^{133}$ In other words, it unambiguously extends constitutional recognition to those Aboriginal and treaty rights that are said to "exist."

The Constitution Act, 1982, however, did not specify these rights. This was to be done, at least in part, through a series of conferences to be held under s. $37 .{ }^{34}$ According to the Act, each of these conferences was to include "in its agenda constitutional matters that directly affect the Aboriginal peoples of Canada. ${ }^{35}$

The original version of the Constitution Act went on to state explicitly that the agenda was to include "the identification and definition of the rights of those peoples to be included in the Constitution of Canada. ${ }^{36}$ However, this clause was dropped from versions subsequent to April 17, 1983. Nonetheless, it is clear from the Constitutional discussions that took place under $\mathbf{s} .37$ that the primary purpose of these conferences was still to identify and define Aboriginal and treaty rights. This series of conferences ended in 1987. They failed to obtain agreement among the governments and the Aboriginal leadership on the definition and identification of these rights. Therefore, the Constitution Act, 1982 remains unelaborated with respect to specific content. ${ }^{37}$

The question then becomes one of interpreting: "What is the content of constitutionally entrenched Aboriginal and treaty rights in the absence of positive language on the subject?" A lot of intellectual effort has been expended on answering it. However for the sake of clarity, it can be reduced to two primary positions.

The first represents the consensus opinion of governments. It has been identified as the "contingent right" position. This position, as I understand it, assumes the paramountcy of the Canadian state as the foundation of rights. Thus, it asserts that no Aboriginal or treaty right can "exist" in a constitutionally entrenched sense unless and until it has been specifically recognized by Canada either through explicit acts of legislation or court

lbid.

The original Constitution Act, 1982 called for one conference on this topic to be held in 1983 . Three additional conferences (to be held between 1984 and 1987) were added on the basis of amendment. Supra, note 24 at 707.

Ibid.

A positive expression of "inherent" right to self-government was one piece of content that was clearly to be addressed at these conferences. To gain a more complete idea of what the Aboriginal nations determined ought to be considered crucial content, it is useful to examine the agendas for these conferences. 
interpretation. In other words, as Canada is paramount, Aboriginal and treaty rights depend for their existence on formal recognition by the state. Hence, their constitutional existence is "contingent" upon such explicit recognition.

This interpretive frame places heavy reliance on the actual wording used in legislation and by the courts. Thus, it would hold that the actual language of the treaties with Aboriginal nations was authoritative with respect to the constitutional interpretation of the contents of treaty rights. Equally, it would hold that actual legislation and/or court interpretation would be crucial to defining the content of "existing" Aboriginal rights. And, it would assert that there is really very little content to these rights because, on the one hand, there was, with the possible exception of the Royal Proclamation of 1763 and the Constitutional provisions for negotiating land claims, no specific legislation that put such rights into existence and, on the other, no court interpretations that explicitly held that existing Aboriginal rights include any right except, primarily, the right to hunt and fish on unoccupied Crown land, subject to regulation by the Crown.

This thesis is consistent with the presumption contained in the preambles of the two constitution acts as outlined above that Canada represents an initial condition of sovereignty over its land mass. Therefore, any Aboriginal or treaty right must be "contingent" upon Canada's existence as a state and hence on Canada's express recognition of it. As sovereignty has yet to be expressly acknowledged by the state, it cannot exist in a constitutional sense. Hence, this interpretive frame supports the views on the doubtful nature of Aboriginal sovereignty and the legitimacy of a unilateral extinguishment through the assertion of sovereignty by Great Britain that were enunciated by the Attorney General of Canada in the case cited above.

The second position is the one espoused by Aboriginal leaders. It has been termed the "inherent right" position. It suggests that Aboriginal rights came into existence before the Canadian state and can continue to exist independently of the creation of Canada. Thus, as these rights are inherent, they do not need to be given explicit legislative sanction to be put into effect. This implies that the main function of the words concerning "existing" in s. 35 was to incorporate recognition of these rights into the Canadian constitution. I will discuss this interpretation at more length below.

\section{RECENT SUPREME COURT DECISIONS AND CONSTITUTIONAL INTERPRETATION}

In the years since the passage of the Constitution Act, 1982 the Supreme Court of Canada has made a number of key decisions regarding the interpretation of Aboriginal and treaty rights in light of provisions contained in s. 35. Of these, three essential decisions were made in the spring of 1990 . These are Horseman, ${ }^{38}$ Sioui $^{39}$ and Sparrow. ${ }^{40}$ In

\footnotetext{
3k. R. v. Horseman, [1990] 4 W.W.R. 97 (S.C.C.).

39. R. v. Sioui (1990), 70 D.L.R. (4th) 427 (S.C.C.).

40. Supra, note 15.
} 
this brief overview, I will not examine these three decisions in detail, but rather will focus primarily on the one that $I$ interpret as most basic to the understanding of the nature of Aboriginal and treaty rights with respect to the questions addressed in this paper. This is the Sparrow case.

In brief, the Sparrow case concerns an Aboriginal right to fish in British Columbia for the Musqueam people, an Aboriginal nation that never signed a treaty. The questions in this case of particular note to this discussion, then, are: whether this right pre-existed Canada and, if so, whether it was automatically cancelled, either through Canada's assertion of sovereignty or through valid legislative acts of Canada or British Columbia, subsequent to Canada's assertion of sovereignty.

As the discussion that follows will show, the Sparrow case does provide strong support for the contention that Aboriginal rights did preexist Canada and that they continue to exist despite the mere assertion of sovereignty by Canada or acts of Parliament. However, the case has a "down side" from the perspective of the "inherent" rights thesis for, with respect to the specific issue addressed here, the Court appears to accept the premise that Aboriginal sovereignty, if it ever existed, was extinguished by the assertion of sovereignty by Great Britain and Canada.

With regard to the existence of Aboriginal rights prior to the establishment of Canada, the Court comes out strongly in favour of the "inherent right" thesis for it asserts that Aboriginal rights (in their words on this point "Indian title") arise independently of and prior to Canada's coming into being. Thus, the Court makes reference to "the sui generis nature of Indian title...." ${ }^{\prime 41}$ It also asserts that Aboriginal people lived in societies before Canada existed and that this fact forms a basis for identifying Aboriginal rights. Thus, they say with respect to an Aboriginal right to fish salmon:

The evidence reveals that the Musqueam have lived in the area as an organized society long before the coming of European settlers, and that the taking of salmon was an integral part of their lives and remains so to this day. ${ }^{42}$

The Court's response to extinguishment is more complex. On the one hand, it provides support for the line of reasoning favoured by the Attomey-General of Canada cited above with respect to the question of the unilateral extinguishment of sovereignty. Thus the Court asserts:

It is worth recalling that while British policy toward the native population was based on respect for their right to occupy their traditional lands, a proposition to which the Royal Proclamation of 1763 bears witness, there was from the outset never any doubt that sovereignty and legislative power, and indeed the underlying title, to such lands vest in the Crown. ${ }^{43}$

\footnotetext{
41. Ibid. at 411 .

42. $\quad$ bid. at 398 .

43. Ibid. at 404.
} 
The Court supports this thesis by reference to the leading United States Supreme Court decision in Johnson v. M'Intosh, ${ }^{44}$ the Royal Proclamation itself, and the leading Canadian Supreme Court decision of Calder v. A.G.B.C. ${ }^{45}$

On the other hand, the court does not support its position that the mere assertion of sovereignty annulled "existing" Aboriginal rights in general. Rather, it argues that such rights, being sui generis in nature, continued to exist without the need for special Constitutional protection after the Crown asserted sovereignty over the land mass of Canada. In this, the court supports the argument outlined by Mr. Justice Hall in the Calder case that British law compels the state to make explicit their intent when government legislates with respect to existing rights. ${ }^{46}$ Thus, it suggests that:

\footnotetext{
The test of extinguishment to be adopted, in our opinion, is that the Sovereign's intention must be clear and plain if it is to extinguish an aboriginal right. ${ }^{47}$
}

Following from the court's reasoning, it is not possible for Canada to assert that acts that "regulated" rights extinguished them. Rather, the acts had to be explicit. Thus, it is plausible that, in the period prior to the Constitution Act, 1982 the sovereign's clear and plain intention could be demonstrated through the passage of very specific, but not constitutionally unusual, acts of Parliament. However, at least since the passage of the Constitution Act, 1982 and its express recognition and affirmation of Aboriginal and treaty rights, the Court greatly constrains the state's ability to act in this area. In fact, it sets out a very specific test for the validity of such legislation. However, it is clear that, if Parliament follows this procedure, it still has the ultimate right to act with respect to Aboriginal and treaty rights.

On one hand, while the Court clearly comes down on the side of the Sovereign's right to extinguish, on the other hand it makes it clear that the "burden of proving extinguishment ${ }^{148}$ is on the Crown and that, unless the Crown can show that it has extinguished an Aboriginal or treaty right clearly and plainly (and, following 1982, in a manner that is constitutionally appropriate), that right continues to exist. This line of reasoning, then, rejects the argument put forward by governments that Aboriginal rights do not exist until they have been given effect by legislation or court pronouncement. Since there are very few explicit acts of Parliament or court decisions explicitly respecting the extinguishment, it can be presumed that, speaking broadly, Aboriginal rights continue to exist.

What Aboriginal rights, then, continue to exist? As a general question, the Court is silent on this point, suggesting only that it will determine this matter on a specific case

\footnotetext{
4. (1823), 8 Wheaton 543.

45. (1973), 34 D.L.R. (3D) 145 (S.C.C.).

4. Asch, supra, note 6.

47. Supra, note 15 at 401

48. Ibid.
} 
basis. In this determination, the Court notes, the burden of proof will rest with the Aboriginal side advocating the Aboriginal right.

The Court in Sparrow, as discussed above, is much more explicit regarding the question of whether Aboriginal ultimate sovereignty is an existing Aboriginal right. ${ }^{49}$ It seems to come down strongly in the negative for, to reiterate, the Court states:

There was from the outset never any doubt that sovereignty and legislative power, and indeed the underlying title, to such lands vest(ed) in the Crown. ${ }^{\text {s) }}$

It is also true that the Sparrow case is not the last word on the subject. Indeed, there are places in other recent Supreme Court decisions that support the idea that Aboriginal sovereignty existed at the time of contact and that it was recognized by the Crown. One of these is the remark made by (now Chief) Justice Lamar in the Sioui case to the effect that the British treated Aboriginal nations with as much freedom as possible. There are other arguments that could be made. One, for example, could be based on an interpretation of the Royal Proclamation of 1763 which, counter to its use by the Court in Sparrow, would argue that the Proclamation, as for example in the use of the phrase "hunting grounds" to describe the territory of Aboriginal nations, refers to these nations as sovereign bodies and that its intent is to assure these nations that the Crown must first enter into treaty when the colonies wish to expand into their domains. ${ }^{51}$

To sum up, the Supreme Court has not definitively answered the questions of whether or not an Aboriginal right to sovereignty existed in the past; it was recognized by the Crown; or it continues to exist, notwithstanding the existence of Canada as a state. The Sparrow decision favours an interpretation that suggests that Aboriginal rights are "sui generis" and that they become a burden on the Crown when it becomes sovereign. However, it raises no doubts about that sovereignty and its extension to Aboriginal nations. Thus, although there are reasonable interpretations of court decisions and other documents to the contrary, the Sparrow decision, which is the most recent discussion of this topic by the Court, supports the thesis that such a right does not continue to exist.

In light of the above, I think it is fair to conclude that, as a minimum, there is nothing definitive in recent Supreme Court decisions to counter the thesis of the Attomey-General

In a recent article (M. Asch and P. Macklem, "Aboriginal Rights and Canadian Sovereignty: An Essay on R. v. Sparrow" (1991) 29 Alta. L. Rev. 498), Macklem and I argue that Sparrow only addresses "ultimate" sovereignty and that it may well be the case that the Court may accept that an inherent right to internal self-government still exists.

Supra, note 15 at 401 . It might also be argued that the Supreme Court's comments here are obiter and therefore do not have legal consequence. This is a reasonable argument for the question of Aboriginal sovereignty was not included in the case. However, I believe the Court has made it quite clear the direction it is likely to take on this question. I therefore do not consider it to be inconsequential with respect to legal theory.

s1. M. Asch, "Wildlife: Defining the Animals, the Dene Hunt and the Settlement of Aboriginal Rights Claims" (1989) 15 Canadian Public Policy 205 at 218. 
of Canada that "if (any Aboriginal nation) ever had sovereignty, it was extinguished completely by the assertion of sovereignty by Great Britain"52 and to help restrain governments from basing their policies on such a thesis.

\section{CANADIAN STATE POLICY AND ABORIGINAL SOVEREIGNTY}

It is therefore not surprising that Canadian policy with respect to the constitutional entrenchment of Aboriginal self-government, at both the federal and provincial levels, has been advanced in a manner consistent with the contingent right thesis. At the same time, as I understand it, the Sparrow decision has resulted in some movement in Federal policy away from an approach with respect to hunting and fishing rights that is based on the assumption that Aboriginal rights generally no longer exist and towards one that accepts an inherent rights thesis based on the premise that, in the absence of specific legislation to the contrary, such Aboriginal rights still exist. Indeed, I am informed, this latter point has resulted in certain changes in the TFN Agreement-in-Principle which are favourable to the Inuit point of view.

The governments of Canada have remained faithful to the proposition that Canadian state sovereignty "extinguished" Aboriginal sovereignty as an orienting principle in negotiations with Aboriginal nations concerning Aboriginal self-government. The following are two examples. First, Canadian governments argued in the first First Ministers' Conferences on Aboriginal issues that recognition of the legislative authority of Aboriginal governments as co-equal to the provinces and the Federal government in their areas of jurisdiction would have to await an explicit constitutional amendment to come into effect. Indeed, the Federal government refused to interpret s. 91(24) of the Constitution Act, 1867 as an opportunity to assert such recognition independently of the current amending formula which requires passage by both the Federal Parliament and by the legislatures of $2 / 3$ of the provinces representing $50 \%$ of the population.

Second, governments have insisted that, until this occurs, any self-government agreements with Aboriginal nations be based either on the principle of "delegated authority" (or a form that expressly acknowledges the sovereignty of the provinces and the Federal government) or through a form of "legislative authority," as in the case of the Sechelt legislation, ${ }^{53}$ which can be unilaterally changed or withdrawn by the Federal parliament. It is still, as Sal Weaver points out in a recent paper:

52. Supra, note 18.

53. Seschelt Indian Band Self-Government Act, S.C. 1986, c. 27. 
More generally, by 1990 much remained the same. The Indian Act remained largely intact. Disagreement over the sources of authority for Indian government continued as the federal position on delegated federal authority remained as firm as the First Nations position on the inherent sovereignty of Indian Nations. ${ }^{\text {st }}$

This position is well-illustrated in the February 6, 1990 response of then Minister Cadieux to a request by Chief Bill Erasmus of the Dene Nation on the topic of self-government negotiations in the context of Dene land claims. The letter provides the Dene with the response of the Federal cabinet to its review "regarding the inclusion of self-government agreements in northern land claims settlements...." ${ }^{.55}$ These settlements, of course, represent constitutional documents according to s. 35 of the Constitution Act, 1982. Hence, any self-government agreements that were contained with them would automatically receive constitutional recognition.

Cabinet specifically rejects such an approach. The letter states that, while land claims agreements are protected, "...the separately created self-government institutions would not themselves be constitutionally protected pursuant to s. 35 of the Constitution Act, 1982." ${ }^{36}$ Again, with respect to any self-government arrangements that might be negotiated with the Federal or the territorial government, the Minister states "...there would not be constitutional protection to the exercise of rights not otherwise provided in claims agreements. ${ }^{.57}$ Rather, Cabinet supports the use of the general amending formula to give effect to Aboriginal self-government. ${ }^{58}$

The stated rationale for this viewpoint is that "such an approach will provide an equitable basis for groups everywhere in Canada to receive constitutional protection of negotiated self-government arrangements. ${ }^{159}$ Another rationale, however, is that Cabinet supports the idea that the Aboriginal right to self-government is "contingent" and hence requires positive action by the state.

Premier Rae of Ontario recently articulated support for an "inherent" right to Aboriginal self-government. ${ }^{60} \mathrm{He}$, thus, becomes the first government leader now in power who is prepared to support this point of view. The consensus of government leaders now in

S. Weaver, "Self-Government Policy for Indians, 1980-1990: Political Transformation or Symbolic Gestures" (Address to the 1989 UNESCO Conference on Migration and the Transformation of Cultures in Canada, 21-22, October 1989) [unpublished].

3. Letter from Pierre H. Cadieux, Minister of Indian Affairs and Northern Development, to Bill Erasmus, President, Dene Nation (6 February, 1990).

Supra, note 18.

lbid.

It is important to note that Cabinet is insisting on the use of the general amending formula notwithstanding that the agreement would pertain only to the Northwest Territories and hence is completely under the jurisdiction of the Govermment of Canada.

Supra, note 18.

B. Rae, "Transcript of Remarks by Premier Bob Rae to the Assembly of First Nations Banquet," University of Toronto, 2 October, 1990 [unpublished]. 
power, then, still follows philosophical orientation that supports the viewpoint on extinguishment and the assertion of sovereignty articulated by the Attorney-General of Canada in the case cited above.

\section{DISCUSSION}

The above discussion indicates that our Constitution Acts and Court decisions do nothing to authoritatively refute the thesis of the Attorney-General of Canada that Aboriginal nations may not have had sovereignty at the time of contact and that, even if this were the case, Aboriginal sovereignty was extinguished by the mere assertion of sovereignty by Great Britain and, later, Canada. It is especially noteworthy that this thesis finds comfort in the recent Sparrow case which, in other respects, represents strong support for the survival of Aboriginal rights to the present. It is therefore not surprising that government policy on Aboriginal self-government remains consistent with this thesis.

The issue, then, is not that the Attorney-General made a statement that is inconsistent with our constitutional ideology, but rather that it remains consistent with at least one interpretation of it. The question is how can this be true? The problem, as I see it, is that it seems self-evident that this theory of Aboriginal sovereignty and its extinguishment does violence to universally accepted fundamental principles of justice and human rights in the modern world such as the assumed equality of peoples, especially of their ability to govern themselves and the basic right of a people to self-determination. These are principles that Canada and Canadians have been proud to advocate on the world stage and especially with respect to the rights of colonized peoples such as the Blacks in South Africa. Hence, it is abhorrent that such a theory remains consistent with our own constitutional ideology. Clearly, then, given the accepted standards of world "morality" and Canada's advocacy of it, the maintenance of such values with respect to Canada itself is contradictory and, in my view, must be changed.

What, then, needs changing? In my view, the key to any thesis regarding Aboriginal sovereignty and its extinguishment derives most basically from the set of presuppositions used by Great Britain and later adopted by Canada to assert the legitimate right to self-government over its land mass.

As Slattery ${ }^{61}$ points out, there are four principle legal means in English law by which a state can justify the acquisition of new territories. These are by reference to: (1) conquest or the military subjugation of a territory over which the ruler clearly expresses the desire to assume sovereignty on a permanent basis; (2) cession or the formal transfer of a territory (by treaty for example) from one independent political unit to another; (3) annexation or the assertion of sovereignty over another political entity without military action or treaty; or (4) the settlement or acquisition of territory that was previously 
unoccupied or is not recognized as belonging to another political entity. To these, Slattery has added (5) "prescription"; a thesis that derives from international law. As Slattery suggests:

...[I]t may be argued that for reasons associated with other basic values and principles of justices, territories illegitimately acquired may sometimes, by passage of time, be transformed into legitimate dominions - a process traditionally termed "prescription."

It is easy to imagine the use of any of these arguments in defense of Canada's claim to the occupation of its territory. It is also clear that the use of these arguments might well be successful in a legal forum, such as an international court of law. Indeed, I would doubt that there would be much support among members of the international community for any such court challenge for Canada is recognized by the world community as being in effective occupation of its territory and, due to the evidence now required to prove a self-evident case of colonialism, protected from the practical impact of relevant United Nations Declarations on the rights of colonized peoples. ${ }^{63}$

However, each of these grounds has certain defects when used as a fundamental orienting principle for constitutional identity with respect to Aboriginal sovereignty. ${ }^{\text {64 }}$ One approach, conquest, was roundly and convincingly condemned by Bill Wilson, an Aboriginal leader from British Columbia when he stated at the First Minister's Conference on Aboriginal issues:

\begin{abstract}
When the German forces occupied France, did the French people believe they didn't own the country? I sincerely doubt that there was a French person in France during the war that ever had the belief that France belonged to Germany, which is why, of course, they struggled with our assistance to liberate their country and once again take it back for themselves. ${ }^{\text {.5 }}$
\end{abstract}

A similar logic applies to annexation and the prescription positions. The former is an argument that suggests that the legitimacy of a new sovereign over a conquered or annexed territory derives less from the standing of the aggressor than from the will of the victims of that aggression. The latter suggests that somehow through the passage of time an act that is manifestly illegitimate can become legitimized. Neither premise is congruent with either the philosophy of decolonization nor with the universal support in the world community for the acts by which former colonizing powers relinquished their claims to sovereignty over their colonies, even in cases where the regime had lasted hundreds of years.

B. Slattery, "Aboriginal Sovereignty and Imperial Claims," supra, note 23 at 19.

Asch, supra, note 6 at 39 .

For an alternative approach to this material see M. Davies, "Aspects of Aboriginal Rights in International Law" in Bradford Morse, ed. Aboriginal Peoples and the Law: Indian. Metis and Imuit Rights in Canada (Ottawa: Carleton Library Series, 1985) 16 at 34.

Asch, supra, note 6 at 29. 
The two other premises for the acquisition of new territories are more specifically applicable to Canada's legal and political view of its own case. Below, I will discuss the "cession" thesis. First, I will discuss the settlement thesis for it is clear that this is the theory that provides support for the assertion of the Attorney-General regarding Aboriginal sovereignty and its extinguishment of the assertion of sovereignty by Great Britain as well as for the Supreme Court of Canada's view, as expressed in Sparrow, that Great Britain could legitimately assert sovereignty "from the outset."

The "settlement" thesis is perfectly justifiable, even within contemporary ideology, in one case: where there really were no previous occupants of the land. The justification becomes troublesome only in the situation where the assertion is made in the face of evidence of human occupation contemporaneous with the first assertion of sovereignty. In this case, the justification must be transformed into an argument about the nature of the population that occupied the land base and its attributes, in particular, with respect to indigenous sovereignty and its survival. ${ }^{67}$

I am aware of at least four arguments that are brought forward to justify the assertion of "settlement" in the face of contemporaneous occupation by another population. ${ }^{68}$ One of these, to my knowledge, is unique to a particular situation. It is the argument put forth by Israel that it is the Jewish population that is truly the "earlier" occupants and that the claims of those "others" who happened to live in the land base of Israel at the time of the assertion of Israeli sovereignty who really are the later arrivals.

The second argument is that there are no original people; that, rather, all are immigrants. This is the type of argument that I have heard mounted in the United States of America with respect to the assertion of special rights on the part of Aboriginal nations. However, this is undoubtedly a secondary argument within American state ideology. The primary ideology, which flows from the concept of "domestic dependent nation" developed by the Supreme Court of the United States under Chief Justice Marshall in the case of Worcester v. Georgia ${ }^{69}$ tends more to a rationale based on the concept of "conquest" 70 than on the argument I advance here. It is thus subject to the type of criticism exemplified in Bill Wilson's remarks cited above.

Supra, note 15.

There are a number of discussions on this point, two such discussions are: Asch, supra, note 6 at 41-54 and Slattery, (1991) supra, note 23.

These examples are intended to serve only as illustrations of the range of possibilities of which I am aware. I am citing them based on my general knowledge of the various cases. This knowledge is derived mainly from reading contemporary newspapers and scholarly joumals. I do know in detail how well each illustration reflects legal thinking or political policy of the example mentioned. Therefore, I am not asserting that these views are the "authorative" or "official" views, but only that they exist and seem to play a significant role in the constitutional ideology of each.

(1832), 31 U.S. (6 Pet.) 515.

P. Macklem, supra, note 23 at $403-406$. 
The third, which I have heard most frequently in the context of Mexico and Latin America, asserts that the settlement thesis is legitimate because everyone in the state is "Aboriginal." This thesis is based on assumptions such as the idea that, through intermarriage and other institutions, there has been a true integration of the descendants of the Aboriginal people and of the colonists into a single society. Therefore, the state represents a single people that is the outcome of the combining of cultures and biology. I am uncertain of the status of this thesis within Latin American constitutional ideology. However, I doubt if it is significant within the context of constitutional documents and court interpretations. I would guess that other ideas, such as the one discussed below as well as the conquest thesis play a more significant role.

Let me hasten to add that this thesis could well be reasonable and, indeed, fit within the "cession" thesis as I will outline it below, were it factually correct - but it is not. Despite intermarriage and the reshaping of indigenous institutions through the impact of colonialism, Aboriginal collectivities exist today that still see themselves as autonomous from the national culture and polity.

The fourth is the version that is the most typical of colonial regimes, especially in pre-Second war Africa and Asia. This version asserts that the settlers were "superior" to the original inhabitants, especially with respect to something akin to political sovereignty. Hence, the land base, when examined with respect to competing claims of the settlers and the original inhabitants, must be more appropriately in the hands of the former. Styles of this version began with colonial expansion and included such particulars as the superiority of Christianity over heathen religions, of agriculture over hunting and gathering, of western cultural institutions such as private property over non-western ones, and, of course, of one skin colour over another. ${ }^{71}$

It is precisely the fourth version of the settlement thesis that lies behind the remarks of the Attorney General for it is only when it is framed from the perspective on the inherent superiority of British and Canadian society that one can make logical sense of the remark that "If the Plaintiff ever had sovereignty, it was extinguished completely by the assertion of sovereignty by Great Britain." No other interpretative frame used to justify the acquisition of new territories by a sovereign can make sense of this remark. ${ }^{72}$

71. Asch, supra, note 6. To the extent that the America thesis, following from Marshall, C. J.'s earlier decisions in Fletcher v. Peck (1810), 10 U.S. (6 Cranch) 87, and Johnson v. M'Intosh (1823), 21 U.S. (8 Wheat.) 543, is consonant with the "settlement" thesis, it reflects this point of view: Macklem, (1991), supra, note 23 at 397; and Slattery, (1991), supra, note 23.

72. There are other interpretative frames. One would suggest that this vision of the assertion of sovereignty would be the same even in situations where the claim is made with respect to land inhabited by English people and it is thus does not attend specifically to inferiority based on skin colour or culture. This may well be the more general case, for, in effect, the sovereign, in a Hobbsean universe, may hold sovereignty with respect to his/her own subjects even without their consent. This, however, does not detract from the particular point that, in situations of colonialism, there is a clear link between a thesis which asserts immediate sovereignty over another culture or people and an assumption that these peoples are, in some significant respect, inferior in comparison 
The "cession" thesis represents the final means by which a state can legally justify the acquisition of new territories. This thesis is based on the presumption of a formal transfer of sovereignty from one power to another, as through a treaty. Cession ranks as an important legal justification for Canadian sovereignty, but, as I will outline below, it is still subordinate to the "settlement" thesis in constitutional ideology. In support of the cession thesis, Canada can point to the existence of treaties (such as the numbered treaties on the Plains), and especially to their written versions. Of particular importance here, of course, is the clause, found in all post-confederation treaties, that conveys the idea, as found in the words of Treaty \#4, that:

(the said) Indians... cede, release, surrender and yield up to the Government of the Dominion of Canada, for Her Majesty the Queen, and Her successors forever, all their rights, titles and privileges whatsoever, to the lands included.... ${ }^{73}$

Thus, it is not hard to imagine that, were Canada to be met with a court challenge on sovereignty within a treaty area, the Attorney-General might well use the argument of "cession" rather than that of "settlement" as was employed in the Gitksan case.

Were these treaties formal cessions as they appear to be in their written versions, Canada's argument regarding legitimacy might gain stature, at least in those regions covered by treaty. But, in fact, do the treaties represent formal cessions, based on the "free will" of the Aboriginal nations, that cede unilateral sovereignty to the British Crown?" That is, are the written versions of the treaties factually accurate? There are strong doubts. In the first place, Aboriginal nations from all over Canada argue that the written versions are not accurate; that, in fact, treaties were produced for "peace and friendship" and to allow for peaceful settlement of non-Natives on Aboriginal lands and/or to form a political relationship based on the concept of sharing stewardship of the lands between the two peoples; but were never considered to provide unilateral cessions of sovereignty to the British Crown. ${ }^{74}$

The possibility that the written versions of treaties are not accurate reflections of the negotiations is supported by the Supreme Court which has suggested as for example in Sioui that, where the language of the treaty is ambiguous, the assessment of the benefit

to the colonial occupier. I am grateful to Brian Slattery for pointing out the delicate nature of the point I am making here.

73. Asch, supra, note 6 at 59.

74. For a discussion of Aboriginal views of treaties on the plains, see J. Foster, "Indian-White Relations in the Prairie West During the Fur Trade Period - A Compact?" in R. Price, ed., The Spirit of Alberta Indian Treaties (Edmonton: Pica Pica Press, University of Alberta, 1987) 181 at 190 and R.T. Price, Legacy: Indian Treaty Relationships (Edmonton: Plains Publishing Company, 1991) at 20. Price concludes his discussion by saying:

The mutual, ongoing political and economic relationships spelled out at the time of the treaties are an essential part of the fabric of Canadian history. Further negotiation and resolution of continuing concerns are required. 
of the doubt must favour the Aboriginal interpretation. As well in the Paulette case, ${ }^{75}$ where the trial judge was able to hear Aboriginal signatories to a treaty first hand, doubts were expressed as to the accuracy of the specific and unambiguous clause that ceded the lands to Canada.

What is the importance of the "cession" thesis in our constitutional ideology? If "cession" were the dominant theme, then, Canada would act differently with regard to Aboriginal nations in at least one respect: it would ensure that treaties of cession were made before it asserted sovereignty in any new territory. Thus, in the case cited in the Attorney-General's remarks, Canada would be actively seeking to negotiate with the Gitksan rather than defend themselves in litigation through the use of the "settlement" theory's presumption of the sovereign's unilateral right to extinguish Aboriginal sovereignty. Equally, the Federal government would not limit its language on self-government in comprehensive land claims agreements to that found in s. 7.1.5 of the Dene-Metis Final Agreement which states that "Nothing in this agreement is intended to affect any Aboriginal or treaty right to self-government which the Dene/Metis may have." Rather, Canada would accept the continued existence of such self-government until "cession" had taken place. Finally, if cession were a primary aspect for justification, our constitution would likely express this fact in its ideology. It is, thus, apparent that the "settlement" thesis forms the basis for our constitutional ideology even where presumed "cessions" have already taken place.

\section{CONCLUSIONS}

Clearly, the colonialist version of the settlement thesis lies at the heart of our constitutional identity with respect to the justification of our occupation of the land mass of Canada in the face of Aboriginal claims to self-determination and self-government. This is the reason for my assertion that Canadian constitutional ideology structurally implies premises that are racist and colonial.

How, then, did Canada arrive at this unfortunate situation? Clearly, there are a number of answers that range from historical traditions and the self-serving political interests of politicians bent on maintaining the status quo to fears of accepting any alternatives and underlying ideological premises. Here, I wish to focus only on the latter two: fears and limitations of current ideological premises. I begin with the latter.

I have argued that our current ideological premise is "universalism." This thesis, as Smith ${ }^{76}$ points out, produces an inexorable force towards the assimilation of minorities into the culture of the majority. The question is how this is achieved. A measure of the answer lies in the very way universalism models the relationship between the state and its citizens. Because this thesis focuses on the presupposition that the state must only see

Supra, note 4. 
individuals and, within that context, sees each individual as structurally equal (or identical), state ideology does not expressly recognize the possible existence of cultural difference within its population. Thus, where there are minority and majority cultures co-existing within a state, state institutions, because they do not recognize cultural difference, become unconsciously structured around the cultural values of the majority. Hence, they generate the assimilative tendency.

The recognition of a pre-existing political society conflicts with universalism in that it supports the existence of a structurally separate community within an ideology that will not accept any community other than that composed of equal individuals who make up "the people." The fact that the pre-existing political society to be recognized is a minority population within the state only heightens the contradiction, for it undermines the legitimacy of the assimilative tendency of state institutions. Better, if one is bound by universalism, to support "majority rule," than inherent rights of minority peoples.

The settlement thesis, then, especially in its colonialist form, fits neatly with universalistic ideology. Universalism suggests that the "majority" is the collective of equal individuals who make up the population of the state. Within this frame, Aboriginal peoples, rather than being conceptualized as a unique collective segment of society, become considered as merely one small component of the total population; one that is required, like the others to accept the domination of the institutions of the majority population. Such a thesis is legitimate to the extent that the "majority" as it is defined by universalism is legitimate.

This is where the thesis of settlement is important. Were Aboriginal sovereignty nonexistent or, at least, extinguished by the mere assertion of sovereignty by great Britain and, later, Canada, then history begins with contact. Thus, as no one can claim "prior" status, the legitimate "majority," becomes the majority that evolved after contact and the legitimate constitutional as well as general history of Canada becomes the constitutional and general history of this "majority." Hence, the settlement thesis, which is itself colonialist in nature, becomes an important foundation for the ideology of universalism which, as it is often expressed, strongly disavows such concepts.

The way out of the structural impasse is to accept the proposition that Canadian constitutional identity is not to be construed as arising from premises, such as the settlement thesis, that presume the inferiority of the Aboriginal nations that now find themselves within Canada. Such an identity would begin, instead, by accepting the thesis that Aboriginal nations were equal sovereigns at the time Europeans first arrived and that this sovereignty remains unextinguished, notwithstanding the existence of Canada, until it is changed by mutual consent. This approach assumes that any modification in the 
status of the parties is based on negotiation and is most likely to find expression by means of a treaty between nations. ${ }^{77}$

The intrinsic value of this approach to constructing constitutional ideology is manifest. On the one hand, it accepts rather than denies the historical fact that Aboriginal nations and European nations were independent sovereigns at the outset of the European experience in the Americas. ${ }^{78}$ On the other, it articulates an orienting vision of constitutional identity that is founded upon the premise of the inherent equality of peoples; a premise that infuses much of contemporary international understanding of all peoples in a post-colonial world, one which upholds the values Canada has expressed within international arenas, and one that seems to be accepted by most Canadians. ${ }^{79}$ Furthermore, it seems self-evident that constitutional premises that accept rather than deny the inherent worth of all parties is the best way to ensure the construction of a healthy, long term relationship between them.

A real block to accepting this kind of structural change is fear. First, there is fear of change itself for this would found Canada on a premise that is radically different than what now exists.

Second, moving Canada away from constitutional premises based on colonialism will have practical implications. These range across a very wide spectrum and include, among many other matters, changes in jurisdictional arrangements, the creation of new funding arrangements, international relations, and the relationship of self-government to the ownership of individual property on the lands of Aboriginal nations. These matters must be addressed and, until they are resolved, can generate much fear, especially among non-Aboriginal Canadians and within the Canadian state. These fears are significant and must be discussed. However, I believe that, with good will and trust, these are practical matters that can be resolved in a mutually satisfactory way. In my view, given the history of this country since the arrival of Europeans, it is only appropriate that the creation of trust, as a precondition for the open participation by Aboriginal nations, depends upon Canada and Canadians freely accepting the premise that constitutional identity must be

77. Given the approaches to the acquisition of sovereignty found in English law, the method that comes closest to the proposition discussed here is "cession." However. there is a unilateral sense to that term which misses an essential aspect of the process described here. Perhaps the phrase "mutual cession" comes closer to capturing this meaning. In any casc, I believe, along with Dickson J. (Guerin) and many others (Slattery, (1987), supra, note 23), that the phrase "sui generis" well describes the process for it is based on an intermingling of Aboriginal and European concepts of relations between nations.

78. Slattery, (1987) supra, note 23 at 733.

79. I do not have survey figures to support this assumption. I am relying on information I glean from discussions, from reading newspapers and journals and from school texts. At minimum. I would say these various sources indicate that few Canadians accept that it would be legitimate for colonial powers to remain in power in former colonies and to support the premise that decolonization was something which was appropriate for Canada to support. 
constructed on the basis of the equality of peoples and expressed through negotiations and treaty-making practices.

Yet, it is fear producing itself to make such a pledge for it opens up the possibility that Aboriginal nations might use it to delegitimize Canadian sovereignty and devalue the status of non-Aboriginal persons who live in Canada. In short, this proposition may be seen as intrinsically threatening and may, thus, be resisted because it is perceived to be divisive and potentially damaging to the integrity of the state at a time of national crisis. $^{80}$

I do not deny the existence of Aboriginal individuals and groups who might advocate positions that imply a delegitimization of Canadian sovereignty and devalue the status of non-Aboriginal persons who live in Canada. ${ }^{81}$ I thus accept that, once advanced by Canada, the proposition of an inherent right to self-government might lead to statements that might be construed by some as damaging. However, I would suggest that, given our colonial history and the ideology it has espoused regarding Aboriginal nations to this point, such a fear must be balanced by the need to put into the record our desire to conduct the construction of our constitutional identity, in the present and the future, in an honourable manner; one that is respectful of the rights of others and true to the ideas we so often state about our understanding of what Canada is and can be both at home and in the world community. In short, I believe we will benefit from freely advocating a proposition based on the equality of peoples regardless of the potential consequences.

At the same time, I do not believe that we need to dwell on the fear that the advocacy of this proposition will necessarily promote the delegitimization of Canadian self-government. In my reading and listening over the years, I find in the statements of virtually all Aboriginal leaders that the objective of their position is to achieve recognition of their sovereignty and not to overturn the sovereignty of the Canadian state. In this sense, they are espousing a position that both European and Aboriginal nations advocated at the outset of European presence on this continent. It is exemplified in the Two-Row-Wampum Treaty of 1664 in which the relationship between the Iroquois and the Dutch was symbolized by a belt of white and purple shell beads which "expressed the relationship as one between equals, peacefully coexisting on this land, Turtle Island"82 and it led, on at least some occasions, to written forms of treaties, such as that between

so. Minister Clark recently suggested that Canada will not accept the concept of "intrinsic" without a definition because the state is concerned that this term is used in the international community as a descriptor for the full sovereign rights of states. He is thus concerned that Aboriginal nations might take claims for sovereignty in the international arena.

81. I once shared a platform with an Aboriginal leader from Alberta who said that there was a boat on the east coast and one on the west coast and argued that the only rights non-Aboriginal peoples have was to decide which boat to take to leave.

k2. "First Nations and the Constitution: Discussion Paper" (Ottawa: Assembly of First Nations, 1991) at 4. 
the Delaware nation and the United States of America in 1778, that are expressed in terms based on premises of "peace and friendship" and the creation of political mutuality. ${ }^{83}$

That Aboriginal nations are not intent on seeking to destroy Canada or devalue non-Aboriginal people, but rather to ensure recognition of their rightful place as co-founders of this nation, was reaffirmed in a recent discussion paper addressed to "Elders, First Nations Citizens, Chiefs and Canadians" and presented at a conference held by the Assembly of First Nations. Here they said:

First Nations are sovereign peoples within Canada and within its provinces and territorics, including Quebec.... We never surrendered this sovereignty; it continues today....First Nations have always related to the other co-founding nations of Canada on a sovereign, equal nation-10-nation basis. ${ }^{k 4}$

Aboriginal nations may advance this position today for moral, philosophical, historical, practical and/or other reasons, but, whatever the reasons, this position is widely held. ${ }^{85}$ Indeed, it has been made clear repeatedly and in many public statements that in general Aboriginal nations, such as the Dene, seek, as the 1975 Dene Declaration suggests:

Independence and self-determination within Canada. This is what we mean when we call for a just land settlement for the Dene Nation. ${ }^{86}$

In short, evidence from history as well as from today clearly indicates that Aboriginal nations are seeking to build, not destroy, Confederation. Given the myriad of regional, ethnonational and other issues that now beset us, it is an approach that, at this time in Canada's constitutional history, needs to be fostered.

83. For the full text see C.J. Kappler, ed., Laws and Treaties, vol. 2 (Washington: Government Printing, 1904) and in particular Articles II and VI.

84. Ihid. at 23.

85. One reason, which Sharon Venne mentioned to me, is that treaties between our nations have granted the non-Indigenous people certain rights and that these need to be recognized.

s. Asch, supra, note 6 at 128. 